\title{
Insect Visitors of Lecythis elliptica H.B.K.'
}

\author{
George C. Jackson and Juan Bauzi Salas ${ }^{2}$
}

INTRODUCTION

Sapucaia nuts, produced by trees of the genus Lecythis are among the most delicious of nuts, and are considered by some superior to Para nuts, Bertholletia excelsa Humb. \& Bonpl., of which this plant is a near relative. This attractive tropical nut tree has been listed as a potential orchard plant and also for its ornamental value $(4)^{3}$.

Plant-accession records of the Federal Experiment Station, Mayagüez, P.R., indicate that the first introduction of Lecythis elliptica H.B.K. into Puerto Rico was made by Dr. Atherton Lee in the form of seed receive from Mr. J. E. Higgins of Summit Gardens, Panamá, on May 8, 1934. The origin of this plant is stated to be Colombia, and, according to Horn (2), 8-year-old seedlings of this introduction flowered and bore its first fruit in Puerto Rico in 1942.

In June 1960, a 2.5-acre orchard of 4-year-old trees obtained from seed of the original introduction was established at the Fortuna Experiment Substation, Fortuna, P.R. Some of these trees bloomed and set their first fruit in the fall of $1961(8)$.

The zygomorphic flowers of Lecythis elliptica H.B.K. are sessile, centripetal and are borne in terminal suprafoliar spikes. The individual blooms have a characteristic odor, are complete, monoclinous, and epigynous. The perianth consists of a calyx of six light-green sepals and six white-yellow petals with light-green veins. The pulvinate fleshy disk of coalesced nectaries and staminodes is arcuate over the androecium and pistil and is appressed or contiguous to the androecium (fig. 1). Such a floral structure indicates that the blooms of this plant should be autogamous or entomophilous rather than anemophilous. These investigations were undertaken

${ }^{1}$ Submitted for publication January 29, 1964. This study was conducted under Federal Grant Project Hatch 94, Plant Introduction and Development of New Crops.

2 Assistant Horticulturist and former Research Assistant, Fruit Experiment Substation, Fortuna, P.R. 00651, respectively. Present address of junior author: Alimentos Borinqueños, S.A., Box 584, Santa Isabel, P.R. 00757. The authors are grateful and wish to express their thanks to Dr. Luis F. Martorell, Entomologist, and Mr. Silverio Medina Gaud, Assistant Entomologist, Agricultural Experiment Station, Río Piedras, P.R. 00928, respectively, for their constructive criticism, reading of the final manuscript, and for the identification and verification of the insects presented
in this study.

${ }^{8}$ Italic numbers in parentheses refer to Literature Cited, pp. 140-1. 
to determine the pollinating agent of $L$. elliplica and to conduct a survey of the insect fauna of this plant.

\section{PROCEDURE}

To determine the possibilities of the flowers being autogamous, all blooms in anthesis were removed and the infloresences then sprayed with Volck-

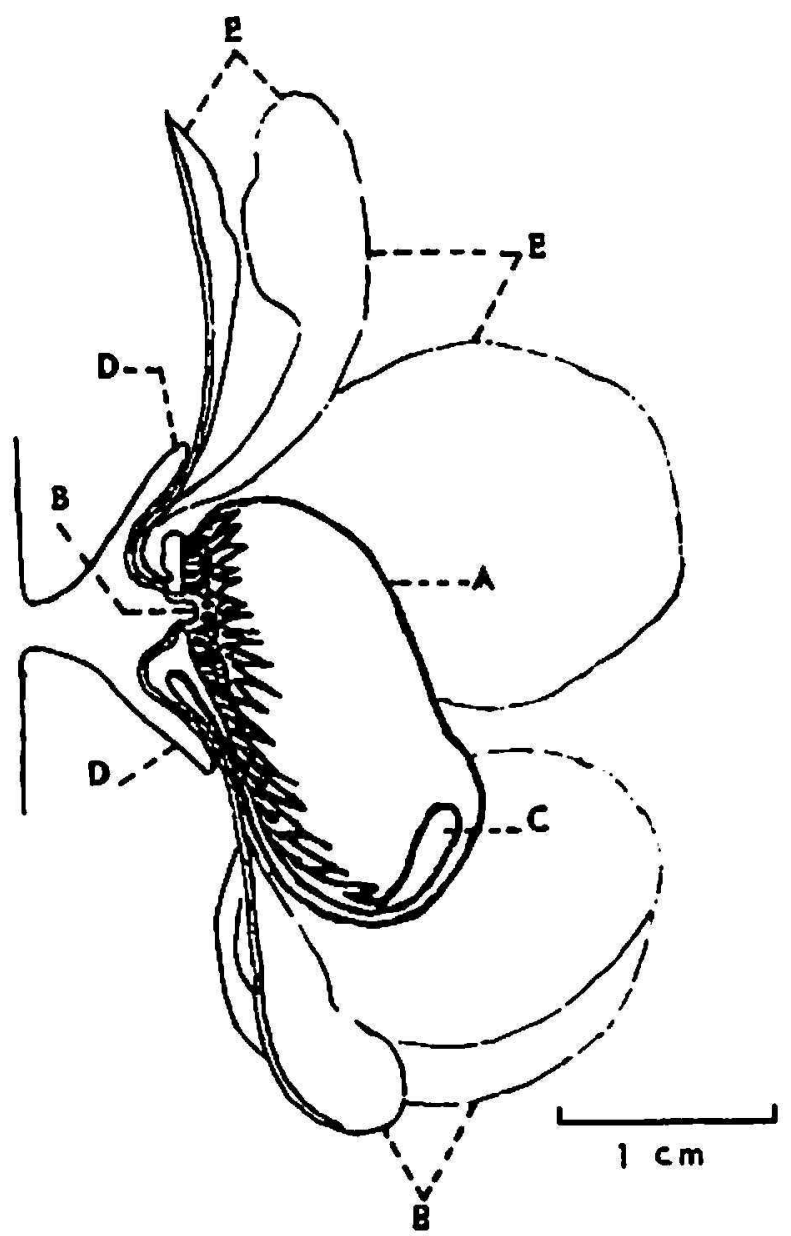

FIa. 1.-Lecythis elliptica H.B.K.: Flower, vertical cross-section: A, Pulvinate fleshy disk appressed to the androecium; B, stigma: C, nectary; D, sepals; E, petals. (Drawing by G. C. Jackson)

Isotox ${ }^{4}$ at the rate of $1: 60$. The flower spikes were then covered with paper bags. A band of cotton was wrapped around the stem prior to securing the bag with cord. An adhesive was applied to the stem below the bag as a further control for crawling and hopping insects. Unopened flower buds were allowed to develop and open under these controlled conditions.

To determine the value of small crawling and hopping insects as pol-

4 No endorsement of products named is intended nor is criticism implied of similar products which were not used. 
linators, all blooms in anthesis were removed and the infloresences covered with bags made of cheesecloth, and secured in place with cord. Such conditions allowed development and blooming of flower buds and permitted movement of small insects.

The oiled-glass microscope-slide technique (11) was employed to investigate the efficiency of wind as a pollinating agent. The prepared microscope slides were placed 3 and 6 feet away on the leeward side of plants having blooms in anthesis. All slides were exposed for 6 hours, after which they were collected and examined.

To investigate the attractiveness of nectar to insects, total soluble solids of the nectar were determined on a laboratory refractometer, employing the methods used by Park (8).

To intercept insects which might serve as pollinators, the plants were visited periodically at different daily time intervals throughout the blooming season. During the course of these investigations, all insects observed on $L$. elliptica were collected for identification and verification.

\section{RESULTS AND DISCUSSION}

Of the infloresences that were covered with paper bags, none set fruit. This indicates that the flowers are apparently allogamous and not autogamous.

Of the infloresences that were covered with cheesecloth bags, none set fruit. Thrips and ants were observed entering or inside of flowers in anthesis, and passing through the mesh of the protective bags. It is improbable that these insects contribute to the pollination of the flowers of this plant.

No pollen grains were observed adhering to the oiled-glass microscope slides. This suggests that the wind is not, or at the most, is a relatively inefficient pollen-disseminating agent.

Nectars of 16 flowers in anthesis were tested and yielded nectar containing 23.8- to 31.8-percent total soluble solids, with a mean average of 27.8 percent. This total soluble-solids percentage is lower than that of most nectarsupplying plants which range between 40 and 55 percent (7), but is higher than that of the common pear, Pyrus spp. (6).

Only insects of the Orders THYSANOPTERA and HYMENOPTERA were observed inside, entering, or leaving flowers during anthesis. All insects observed on L. elliptica are recorded as listed:

\section{INSECTS OBSERVED ON L. elliptica}

\section{ORDER ORTHOPTERA:}

\section{Family Blattidae}

Plecloplera dorsalis (Burmeister), on flowerbuds 
ORDER NEUROPTERA:

Family Chrysopidae

Chrysopa sp., near collaris Schneider, on foliage, branches, and twigs Unidentified aphislion larvae, on foliage, branches, and twigs ORDER TRICHOPTERA:

One unidentified specimen, on foliage

ORDER THYSANOPTERA:

\section{Family Thripidae}

Frankliniella insularis (Franklin), inside open flowers

ORDER HOMOPTERA:

Family Cicadellidae

Chlorotettix tethys Van Duzee, on foliage and flowerbuds

Family Fulgoridae

Oliarus complectus Ball, on foliage

Family Flatidae

Petrusa marginata (Brunnich), on foliage

Family Coccidae

Vinsonia stellifera (Westwood), on foliage and twigs

Saissetia hemisphaerica (Targioni) on foliage, branches, twigs, and fruit

ORDER HEMIP'TERA:

Family Coreidae

Leploglossus stigma (Herbst), on foliage and flowerbuds

Family Reduviidae

Zelus subimpressus Stal, on foliage and flowerbuds

Family Miridae

Lygus apicalis Fieber, on foliage and flowerbuds

ORDER COLEOPTERA:

Family Elateridae

Chalcolepidius silbermanni Chevrolat, on branches in full sun

Family Lycidae

Thonalmus chevrolati Bourgeois, on foliage

Family Lampyridae

Photinus vittatus Olivier, on underside of foliage

Family Coccinellidae

Cryptolaemus montrouzieri Mulsant, on foliage, twigs, flowers, and flowerbuds

Hyperaspis sp. on foliage, twigs, flowers, and flowerbuds

Curinus coeruleus Mulsant, on foliage, twigs, flowers, and flowerbuds Coelophora inaequalis (Fabr.), on foliage, twigs, flowers, and flowerbuds

Cycloneda sanguinea L., on foliage, twigs, flowers, and flowerbuds 


\section{Family Chrysomelidae}

Hilarocassis exclamationis $\mathrm{L}$., on foliage and twigs

Metriona subsignata Boheman, on foliage and branches

Family Bruchidae

Callosobruchus maculatus Fabricius, on foliage

Family Curculionidae

Diaprepes abbreviata L., feeding on foliage, flower petals, and unopened flowerbuds

ORDER DIPTERA:

Family Sarcophagidae

Sarcophaga lambens Wiedemann, on foliage and flowers

ORDER LEPIDOPTERA:

Family Lycaenidae

Thecla simaethis simaethis (Drury), on foliage

Family Hesperiidae

Ephyriades arcas (Drury), feeding on nectar from side of flowers in anthesis

Family Pyralidae

Argyria diplomachalis Dyar, on foliage

Family Megalopygidae

Megalopyge krugii (Dewitz), pupa-cases on branches

ORDER HYMENOPTERA:

Family Braconidae

Chelonus insularis Cresson, on foliage and branches

Family Ichneumonoidae

Carinodes havanensis (Cameron), on foliage

Family Chalcididae

Brachymeria robusta (Cresson), on foliage

Family Formicidae

Unidentified specimens, inside open flowers, on flowerbuds, leaves, twigs, and branches

Family Sphecidae

Tachyles insularis Cresson, on foliage

Family Scoliidae

Campsomeris trifasciala (F.), females only, feeding on nectar by entering flowers during anthesis

Family Eumenidae

Eumenes ornatus Saussure, on foliage and flowerbuds, nest-building on branches

Family Vespidae

Polistes americanus Fabricius, on foliage and flowers, nest-building on twigs 
P. major Palisot de Beauvois, on foliage and flowers, nest-building on twigs and branches

Mischocyltarus cubensis (Saussure), on foliage, flowerbuds, and open flowers

\section{Family Anthrophoridae}

Exomalopsis globosa (F.), on flowers and flowerbuds

Family Halictidae

Haliclus sp., on leaves and open flowers

Family Xylocopidae

Xylocopa brasilianorum (L.), females only, feeding on nectar by entering flowers in anthesis

\section{Family Apidae}

A pis mellifera $\mathrm{L}$., feeding on nectar from side of flowers in anthesis

The economic importance of the above-listed insects is reported elsewhere in the literature (10).

\section{THE FEMALE CARPLNTER BEE}

The female carpenter bee, Xylocopa brasilianorum (L.), was observed on numerous occasions entering and leaving flowers in anthesis (fig. 2). This bee alights on the pulvinate disk and bodily forces her way headfirst into the flower, brushing the androecium and passing over the stigma with pollen-laden dorsal bristles. After visiting the nectary, she backs out repeating the operation in reverse. In all cases where carpenter bees were observed and collected, prior to flower entry and after departure, pollen was found adhering to the thorax brushes. The length of visits inside the flowers was timed and averaged 11.5 seconds. In all instances observed, pollen was found on the stigmatic surface after carpenter bee visits. This insect has been reported as a pollinator in Dioscorea spp. (5).

\section{OTHER INSECTS}

lemales of the white grub-parasite, Campsomeris trijasciata (F.), were observed in rare instances entering and leaving flowers during anthesis. The procedure of entry and departure was the same as that of $X$. brasilianorum (L.). Pollen was found adhering to the dorsal bristles of all white grub-parasites collected, and also on the stigma of flowers she had visited. Fentes of this species have been reported feeding on nectar of Kallstroemia maxima (L.) T. \& G. and Sida carpinifolia I. (1).

Thrips, Frankiniella insularis (Franklin), were found inside all flowers studied. The greatest concentration of thrips in all instances, was in the staminodes of the pulvinate fleshy disk. Thrips were observed not to carry any pollen on their hodies or legs. Stigmas of some flowers had pollen grains, 
which may have been deposited by other previous insect visitors. This genus of thrips has very little power for sustained flight (9), which suggests that any pollination would likely be from pollen of the same flower.

Ants (Formicidae) were also observed inside all flowers during anthesis.

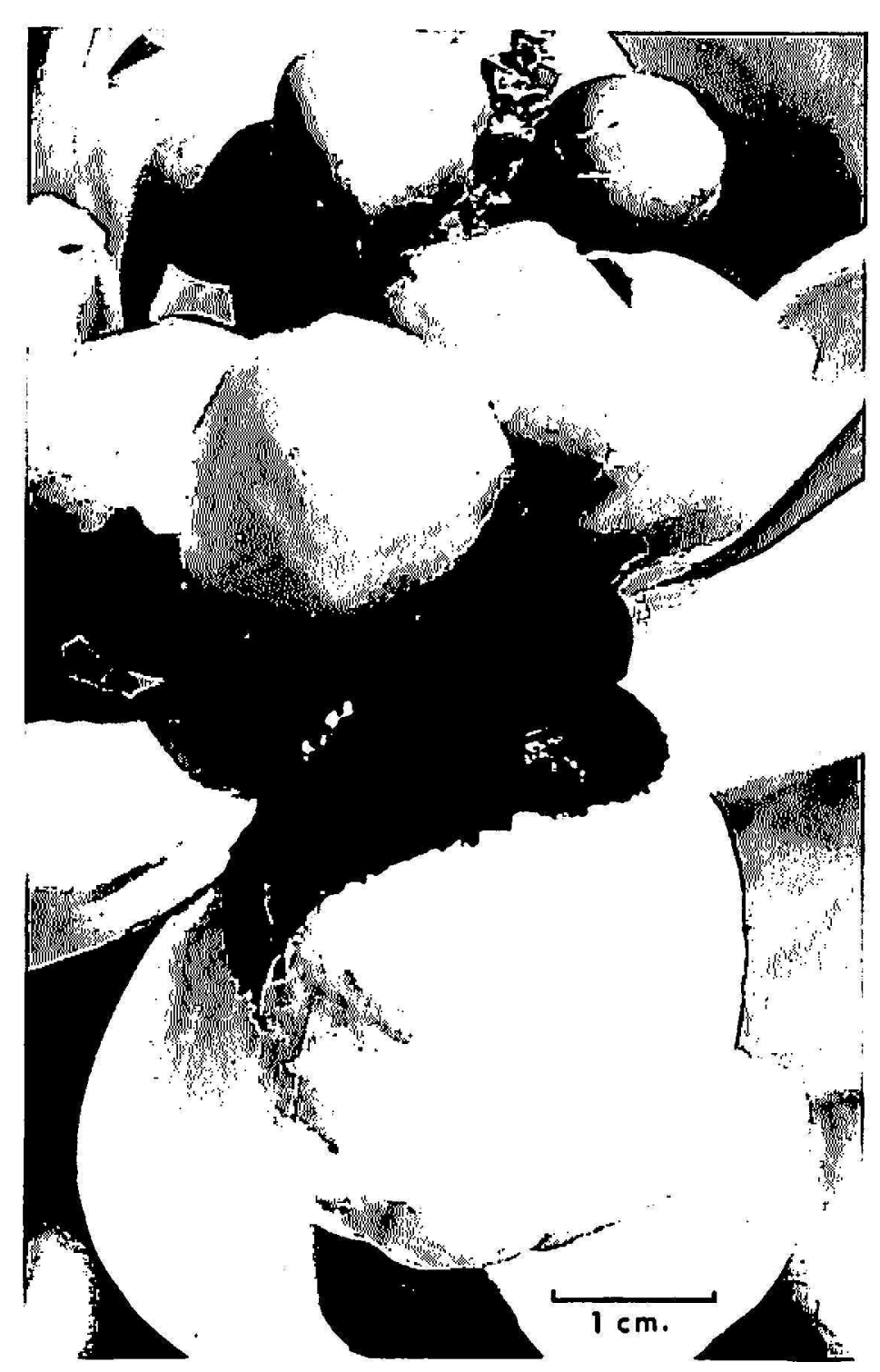

Fig. 2.-A female carpenter bee or "cigarrón", Nylocopa brasilianorum (L.), entering an open flower of the Sapucaia nut, Lerythis elliptica H.B.K.

The greatest concentration of these insects was at the nectary at the base of the pulvinate disk. No pollen grains were found elinging to their bedies or legs. The size of ants as well as thrips, permitted them to enter and depart from open flowers without ever passing near the stigma. Any pollinaticn accomplished by ants would appear accidental rather than nomal.

Slippers (Hesperiidae) and honeybees (Apidae) were observed feeding on neetar. Not being as small as the thrips, $F$. insularis (lranklin), and ants 
(Formicidae), nor having the muscular power of the carpenter bee, $X$. brasilianorum (L.), or the white grub-parasite, C. trifasciata (F.), it is apparently impossible for them to enter the blooms. These insects alight on the side of the pulvinate disk and feed by inserting their sucking-tubes in the nectary at the base of the flower.

\section{CONCLUSIONS}

It may be concluded that the blooms of $L$. elliptica are allogamous and entomophilous, and not autogamous nor anemophilous, with the principal pollinating insect being the female carpenter bee, $X$. brasilianorum, and possibly females of the white grub-parasite, C. trifasciala. Because of the demonstrated nature of the flowers, it is possible but improbable that thrips, (Thripidae) and ants, (Formicidac) contribute to the pollination of this plant.

\section{SUMMARY}

It was found during investigations conducted with the tropical nut tree, Lecythis elliptica H.B.K., that the flowers of this plant are allogamous and not autogamous. The plant is entomophilous and not anemophilous.

A survey of the insect fauna of this plant indicates that no less than 43 species representing 36 families of 10 orders frequent it during the blooming season. Observations also indicate that the primary pollinating insects are the female carpenter bee, Xylocopa brasilianorum (L.), and also females of the white grub-parasite, Campsomeris trifasciata (F.).

\section{RESUMEN}

En el curso de los experimentos realizados con el árbol de nuez tropical, Lecythis elliptica H.B.K., se encontró que su flor es alógama y no autógama. También se comprobó que esta planta es entomófila y no anemófila.

El estudio que se hizo sobre los insectos de este árbol revela que por lo menos 43 especies que representan 36 familias y 10 órdenes visitan el árbol durante la época de la florecida. Las observaciones indican que los principales polinizadores son: el cigarrón, Xylocopa brasilianorum (L.) y la avispa parásita del gusano blanco, Campsomeris trifasciata (F.).

\section{LITERATURE CITED}

1. Box, H. E., Porto Rican cane-grubs and their natural enemies, J. Dept. Agr. P.R. $9(4): 291-356,1925$.

2. Horn, C. L., Report of the P.R. Experiment Station, 1942, USDA pp. 11, June, 1943.

3. Jackson, G. C., Informe semestral Subestación y Finca de Semillas de Frutales, Julio 1 a Diciembre 31, 1961, Univ. P.R. Agr. Lxpt. Sta., pp. 11, Jan., 1962.

4. Kennard, W. C., and Winters, H. F., Some fruits and nuts for the tropies, USDA Misc. Pub. 80, pp. 78, 19150. 
5. Martin, F. W., Cabanillas, E., and Ortiz, S., Natural pollination, hand pollination and crossibility of some Mexican species of Dioscorea., Trop. Agr. Trinidad 40(2): 135-41, 1063.

6. Morse, R. A., That wonderful pollinator . . the honeybee, Amer. Fruit Grower 83(4): 50, 1963.

7. Park, O. W., Studies on nectar in relation to honey production, J. Econ. Ent. 21: 789-90, 1928.

8. Park, O. W., Studies on the changes in nectar concentration produced by the honeybee, A pis mellifera, L., Iowa S. Col. Expt. Sta. Res. B. 151, pp. 215-8, 1932.

9. Warmke, H. E., Studies on pollination of Hevea brasiliensis in Puerto Rico., Sci., 11S(2945): 646-8, 1951.

10. Wolcott, G. N., The insects of Puerto Rico, J. Agr. Univ. P.R., s2: 1-975, 1948.

11. Yamane, G. M., and Nakasone, H. Y., Pollination and fruit set studies of acerola Malpighia glabra, L., in Hawaii., Proc. Amer. Sci. Hort. Sci., 78: 141-8, 1961. 